\title{
Analysis of molecular markers as predictive factors of lymph node involvement in breast carcinoma
}

\author{
LUCIANA MARQUES PAULA ${ }^{1}$, LUIS HENRIQUE FERREIRA DE MORAES ${ }^{2}$, \\ ABAETÉ LEITE DO CANTO ${ }^{3}$, LAURITA DOS SANTOS ${ }^{4}$, AIRTON ABRAHÃO MARTIN ${ }^{4}$, \\ SILVIA REGINA ROGATTO ${ }^{5}$ and RENATA DE AZEVEDO CANEVARI ${ }^{1}$
}

\author{
${ }^{1}$ Laboratory of Molecular Biology of Cancer, Institute of Research and Development (IP\&D), \\ University of Vale do Paraíba, São José dos Campos, 12244-000 São Paulo; ${ }^{2}$ Mastology Department,
}

San Francisco Assis Hospital, Jacareí, 12311-200 São Paulo; ${ }^{3}$ Center for Diagnostic Medicine, Pathology and Cytology

(CIPAX), São José dos Campos, 12243-000 São Paulo; ${ }^{4}$ Laboratory of Biomedical Vibrational Spectroscopy,

Institute of Research and Development (IP\&D), University of Vale do Paraíba, São José dos Campos, 12244-000 São Paulo;

${ }^{5}$ NeoGene Laboratory, Urology Department, Sao Paulo State University, Botucatu, 18618-000 São Paulo, Brazil

Received January 11, 2016; Accepted September 15, 2016

DOI: $10.3892 / \mathrm{ol} .2016 .5438$

\begin{abstract}
Nodal status is the most significant independent prognostic factor in breast cancer. Identification of molecular markers would allow stratification of patients who require surgical assessment of lymph nodes from the large numbers of patients for whom this surgical procedure is unnecessary, thus leading to a more accurate prognosis. However, up to now, the reported studies are preliminary and controversial, and although hundreds of markers have been assessed, few of them have been used in clinical practice for treatment or prognosis in breast cancer. The purpose of the present study was to determine whether protein phosphatase $\mathrm{Mg} 2+/ \mathrm{Mn} 2+$ dependent $1 \mathrm{D}, \beta-1,3-\mathrm{N}$-acetylglucosaminyltransferase, neural precursor cell expressed, developmentally down-regulated 9 , prohibitin, phosphoinositide-3-kinase regulatory subunit 5 (PIK3R5), phosphatidylinositol-5-phosphate 4-kinase type II $\alpha$, TRF1-interacting ankyrin-related ADP-ribose polymerase 2, BCL2 associated agonist of cell death, G2 and S-phase expressed 1 and PAX interacting protein 1 genes, described as prognostic markers in breast cancer in a previous microarray study, are also predictors of lymph node involvement in breast carcinoma Reverse transcription-quantitative polymerase chain reaction analysis was performed on primary breast tumor tissues from women with negative lymph node involvement $(\mathrm{n}=27)$ compared with primary tumor tissues
\end{abstract}

Correspondence to: Dr Renata de Azevedo Canevari, Laboratory of Molecular Biology of Cancer, Institute of Research and Development (IP\&D), University of Vale do Paraíba, 2911 Shishima Hifumi Avenue, São José dos Campos, 12244-000 São Paulo, Brazil E-mail: rcanevari@univap.br

Key words: breast cancer, gene expression, lymph node metastases, molecular markers, predictive factors from women with positive lymph node involvement $(\mathrm{n}=23)$, and was also performed on primary tumors and paired lymph node metastases $(n=11)$. For all genes analyzed, only the PIK3R5 gene exhibited differential expression in samples of primary tumors with positive lymph node involvement compared with primary tumors with negative lymph node involvement $(\mathrm{P}=0.0347)$. These results demonstrate that the PIK3R5 gene may be considered predictive of lymph node involvement in breast carcinoma. Although the other genes evaluated in the present study have been previously characterized to be involved with the development of distant metastases, they did not have predictive potential.

\section{Introduction}

Breast cancer is the fifth most common cause of cancer-related mortalities and the second most common form of non-skin-associated cancer worldwide (1). At present, the most important prognostic factors used to guide decisions regarding adjuvant systemic treatment are tumor size, nodal status, tumor clinical stage, hormone receptor [progesterone receptor (PGR) and estrogen receptor (ER)], human epidermal growth factor receptor 2 (HER2) status (2), and histological grade. Various other clinicopathological factors, including proliferation index and novel molecular markers, have been investigated to improve the prediction of clinical outcome $(3,4)$. Despite improvements in risk stratification, the current prognostic factors exhibit moderate accuracy in classifying breast tumors according to their clinical behaviors. In breast cancer, axillary lymph nodes are typically the initial site of metastasis (5). The presence of lymph node metastasis predicts the development of distant metastases and is considered one of the most informative prognostic factors when evaluating patients with breast cancer (6-8).

Several studies have identified correlations between clinicopathological parameters of patients with breast cancer and a high risk of developing lymph node metastases. Among 
the parameters most significantly correlated with lymph node involvement are histological grade, tumor size and age $(9,10)$. Furthermore, number and proportion of evaluated sentinel lymph node biopsies (SLNBs) have been correlated with metastases in the axillary lymph nodes (11-13). An SLN is defined as one of the first nodes to collect lymphatic fluid from a malignant tumor and malignant cells (1). The result of the SLNB indicates whether complete axillary lymph node dissection (ALND) should be performed (14), which allows complete evaluation of lymph nodes. However, ALND is associated with significant morbidity and is not associated with a significant increase in patient survival (15). Prognostic and predictive tools are required to more accurately select patients for lymph node dissection and spare large numbers of patients undergoing this procedure when it is not necessary.

The advent of polymerase chain reaction (PCR)-based diagnostic methods, in particular reverse transcriptionquantitative PCR (RT-qPCR), made the detection of SLN metastasis (16) and axillary lymph node involvement in breast cancer possible, which resulted in the identification of several molecular markers with significant potential prognosis in relation to risk of axillary and systemic metastases (17-20). The purpose of the present study was to determine whether genes that had been previously described as prognostic markers in breast cancer (21) are also predictors of lymph node involvement in breast carcinoma. The expression of 10 genes [protein phosphatase $\mathrm{Mg} 2+/ \mathrm{Mn} 2+$ dependent 1D (PPM1D), $\beta-1,3-\mathrm{N}$ acetylglucosaminyltransferase (B3GNT7), neural precursor cell expressed developmentally down-regulated 9 (NEDD9), prohibitin (PHB), phosphoinositide-3-kinase regulatory subunit 5 (PIK3R5), phosphatidylinositol-5-phosphate 4-kinase type II $\alpha$ (PIP4K2A), TRF1-interacting ankyrin-related ADP-ribose polymerase 2 (TNKS2), BCL2 associated agonist of cell death (BAD), G2 and S-phase expressed 1 (GTSE1) and PAX interacting protein 1 (PAXIP1)] was analyzed by RT-qPCR in the primary tumor tissues of patients with and without lymph node involvement, in addition to primary tumors and lymph node metastases of the same patients in order to determine whether these genes have predictive power in relation to risk of axillary metastases.

\section{Materials and methods}

Samples and patients. A total of 50 primary tumor samples were collected from 49 patients that underwent segmental resection or mastectomy (1 patient presented with bilateral tumors); 41 samples were obtained from Hospital São Francisco de Assis (Jacareí, Brazil) and 9 were from other hospitals, including Hospital Antoninho da Rocha Marmo, Santos Dumont Hospital and Hospital Pio XII (São José dos Campos, Brazil). Frozen primary breast tumor tissues were collected from women with negative $(n=27)$ and positive $(n=23)$ lymph node status, and, of the positive lymph node cases, primary breast tumors and paired lymph node metastases tissues were acquired from 11 patients. Written informed consent was obtained from all patients during the collection period, and the study was reviewed and approved by the Research Ethics Committee of the University of Taubaté (Taubaté, Brazil) (CEP 554/11). Table I provides a summary of the clinicopathological data from the 50 tumor samples from 49 patients with breast carcinoma related to the status of axillary lymph nodes.

Immediately after surgery, tumor tissue samples were frozen and stored at $-80^{\circ} \mathrm{C}$. To ensure consistency, diagnosis of every specimen was made by a single breast pathologist (Center for Diagnostic Medicine, Pathology and Cytology, São José dos Campos, Brazil). Whenever necessary, tissue samples were macrodissected with a scalpel to guarantee that only sections comprised of $\geq 90 \%$ tumor cells were used for RNA isolation and subsequent gene expression analysis. A total of 5 non-tumor breast tissue samples from patients undergoing mammary reduction, which had been histopathologically confirmed as healthy, were used as controls. Histopathological classification was performed according to the International Classification of Disease for Oncology from the World Health Organization (22), and the clinical stage was determined according to the Union for International Cancer Control Tumor-Node-Metastasis (23) classification. The malignancy of carcinoma infiltration was scored according to the Bloom and Richardson grading system (24).

Total RNA isolation, quantification and synthesis of cDNA. Total RNA was extracted from 50 macrodissected primary tumor samples, 11 lymph nodes and 5 healthy breast tissues using the RNeasy ${ }^{\circledR}$ Lipid Tissue Mini kit (Qiagen, São Paulo, Brazil) according to the manufacturer's protocol. RNA samples were purified with $0.1 \%$ acetate-ethanol, resuspended in RNase-free ultra-pure water and stored at $-80^{\circ} \mathrm{C}$ until use. RNA quality was analyzed by $1 \%$ agarose gel electrophoresis, and the concentration and quality was measured using a NanoDrop-1000 spectrophotometer v.3.7 (Labtrade, Sao Paulo, Brazil). To avoid DNA contamination, RNA samples were treated with the RNase-Free DNase Set (Qiagen) according to the manufacturer's protocol.

cDNA synthesis reactions were carried out in a Peltier Thermal Cycler (MJ-96G; Biocycle Co., Ltd, Hangzhou, China). Total RNA (1 ug) from each sample was reverse transcribed in a $20 \mu \mathrm{l}$ final volume containing $10 \mu \mathrm{l} 2 \mathrm{x}$ first-strand buffer (10 $\mathrm{mm} \mathrm{mgcl}_{2}$, and $1 \mathrm{mmde}$ per dntp), $0.5 \mu \mathrm{l}$ Oligo $(\mathrm{dT})_{20}, 0.5 \mu \mathrm{l}$ random primers, $1 \mu \mathrm{l}$ annealing buffer and $2 \mu \mathrm{l}$ SuperScript ${ }^{\mathrm{TM}}$ III Reverse Transcriptase enzyme (Invitrogen; Thermo Fisher Scientific, Inc., Waltham, MA, USA). RT was carried out for $50 \mathrm{~min}$ at $50^{\circ} \mathrm{C}, 10 \mathrm{~min}$ at $25^{\circ} \mathrm{C}$, followed by $50 \mathrm{~min}$ at $50^{\circ} \mathrm{C}$. The reaction mixture was subsequently inactivated for $5 \mathrm{~min}$ at $85^{\circ} \mathrm{C}$.

Evaluation of transcript expression by RT-qPCR. RT-qPCR reactions for the 10 study genes and the reference gene (MRLP19) were carried out in duplicate on an ABI Prism 7000 Sequence Detection system (Thermo Fisher Scientific, Inc.) using Platinum ${ }^{\circledR} S Y B R^{\circledR}$ Green qPCR SuperMix-UDG (Applied Biosystems; Thermo Fisher Scientific, Inc.) in a total volume of $10 \mu \mathrm{l}$ according to manufacturer's protocol. Primers were designed using Primer Express software (v3.0; Applied Biosystems; Thermo Fisher Scientific, Inc.) and the sequences are presented in Table II. In order to avoid amplification of contaminating genomic DNA, the primers were placed at the junction between the two exons or in a different exon. RT was carried out for $1 \mathrm{cycle}$ of $95^{\circ} \mathrm{C}$ for $10 \mathrm{~min}$, followed by 40 cycles of $15 \mathrm{sec}$ at $95^{\circ} \mathrm{C}$ and $1 \mathrm{~min}$ at $60^{\circ} \mathrm{C}$. A dissociation curve was 
included in all experiments. For all primers, amplification curves were constructed with serial dilutions of healthy breast and breast carcinoma cDNA $(100,20,4,0.8$ and $0.16 \mathrm{ng} / \mu \mathrm{l})$. Standard curves of the targets and reference genes demonstrated similar amplification efficiencies $(>90 \%)$. Quantitative data was analyzed using the Sequence Detection system software (v1.0; Applied Biosystems; Thermo Fisher Scientific, Inc.). The details of the gene-specific RT-qPCR assays are presented in Table II.

Measurements of gene expression were calculated using the relative $\Delta \Delta \mathrm{Cq}$ method, in which the mean $\mathrm{Cq}$ value of each target gene in each sample is subtracted from the mean $\mathrm{Cq}$ value of the reference gene (25). The transcripts of housekeeping genes MRLP19, PPIA, and GAPDH, were quantified as previously described (26), and the MRLP19 gene was selected as an endogenous control, which provided increased accuracy and resolution in the quantitation of gene expression data, facilitating the detection of smaller changes in gene expression than otherwise possible. Normalized expression levels of target gene tumor samples were expressed in fold-change relative to their abundance in a pool of non-tumor breast tissue control samples, which was calculated as follows:

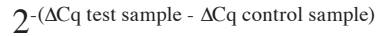

Statistical analysis. Statistical analyses comparing clinicopathological characteristics (including age, histological type, histological grade, ER, PGR, HER2 and Ki-67 status, and tumor stage and size) with the presence or absence of lymph node involvement were performed using IBM SPSS v20.0 and the $\chi^{2}$ test. $\mathrm{P} \leq 0.05$ was considered to indicate a statistically significant difference.

For the analysis of RT-qPCR, the median $2^{-\Delta \Delta C q}$ values for each analyzed group were compared using Fisher's exact test [performed using GraphPad InStat software v5.0 (GraphPad Software, Inc., La Jolla, CA, USA)] to determine whether the relative fold change was significantly different between the two groups. $\mathrm{P} \leq 0.05$ was considered to indicate a statistically significant difference.

\section{Results}

Clinicopathological characteristics. A total of 50 frozen primary breast tissues were obtained from 49 patients (1 patient presented with bilateral tumors). The average age of the patients at diagnosis was 57 years (range, 53-60 years). According to clinicopathological data, $53 \%$ of patients were lymph node-negative and $47 \%$ were lymph node-positive, with the average number of metastatic lymph nodes being 6.04 (range, 1-21). The average age at diagnosis did not differ significantly between those with (53 years) and without (60 years) lymph node metastasis.

Patients were chosen based on sample availability opposed to clinical parameters; therefore, the analyzed tumors represent a variety of pathological characteristics and tumor types. The majority of specimens were from patients with invasive ductal metastasis (84\%), predominantly size T1 and T2 (90\%). The majority of patients had a positive ER $(80 \%), \operatorname{PgR}(78 \%)$ and HER2 (50\%) status. A total of 2 patients were diagnosed with stage-IV breast cancer. A few months after diagnosis, 4 patients developed distant metastasis and 1 succumbed to the
Table I. Clinicopathological data of 50 tumor samples ${ }^{\mathrm{a}}$ from 49 patients with primary breast carcinoma associated with the status of axillary lymph nodes.

\begin{tabular}{|c|c|c|c|}
\hline Features & $\mathrm{n}$ & $\begin{array}{c}\text { Node-positive } \\
\text { n (\%) }\end{array}$ & $\begin{array}{c}\text { Node-negative } \\
\mathrm{n}(\%)\end{array}$ \\
\hline Age, years & 49 & & \\
\hline$\leq 50$ & & $9(18)$ & $5(10)$ \\
\hline$>50$ & & $14(29)$ & $21(43)$ \\
\hline Histology & 50 & & \\
\hline Invasive ductal & & $21(42)$ & $21(42)$ \\
\hline Others (in situ, lobular) & & $2(4)$ & $6(8)$ \\
\hline Grade & $46^{\mathrm{b}}$ & & \\
\hline $1+2$ & & $13(28)$ & $14(30)$ \\
\hline 3 & & $10(22)$ & $9(20)$ \\
\hline ER status & $35^{\mathrm{b}}$ & & \\
\hline Negative & & $2(6)$ & $5(14)$ \\
\hline Positive & & $11(31)$ & $17(49)$ \\
\hline PGR status & $45^{\mathrm{b}}$ & & \\
\hline Negative & & $4(9)$ & $6(13)$ \\
\hline Positive & & $9(20)$ & $26(58)$ \\
\hline HER2 status & $32^{\mathrm{b}}$ & & \\
\hline HER2- & & $4(13)$ & $12(38)$ \\
\hline HER+ & & $8(25)$ & $8(25)$ \\
\hline Ki67 status, \% & $27^{\mathrm{b}}$ & & \\
\hline$>25$ & & $4(15)$ & $5(19)$ \\
\hline$\leq 25$ & & $5(19)$ & $13(48)$ \\
\hline T stage & $48^{\mathrm{b}}$ & & \\
\hline $\mathrm{T} 1+\mathrm{T} 2$ & & $19(40)$ & $24(50)$ \\
\hline $\mathrm{T} 3+\mathrm{T} 4$ & & $3(6)$ & $2(4)$ \\
\hline Tumor size, $\mathrm{cm}$ & $47^{\mathrm{b}}$ & & \\
\hline$\leq 2$ & & $10(21)$ & $11(23)$ \\
\hline$>2$ & & $13(28)$ & $13(28)$ \\
\hline
\end{tabular}

disease. None of the evaluated pathological features differed significantly between groups [primary tumors in women with negative and positive lymph node status: Age, $\mathrm{P}=0.2047$; histological type, $\mathrm{P}=0.2609$; histological grade, $\mathrm{P}=1.0000$; ER status, $\mathrm{P}=0.6889$; PGR status, $\mathrm{P}=0.4411$; HER2 status, $\mathrm{P}=0.2734$; Ki-67 status, $\mathrm{P}=0.4221$; tumor stage, $\mathrm{P}=0.6492$; and tumor size, $\mathrm{P}=1.0000$ (Fisher's exact test, $\mathrm{P} \leq 0.05$ )]. These results indicate that the clinicopathological characteristics in the analyzed samples are not associated with the presence or absence of lymph node metastasis (Table I).

Gene expression. In the present study, the expression of 10 genes (PPM1D, B3GNT7, NEDD9, PHB, PIK3R5, PIP4K2A, TNKS2, BAD, GTSE1 and PAXIP1), which were selected from 58 genes in a previous microarray study (21), was assessed by RT-qPCR in 50 samples from 49 patients 


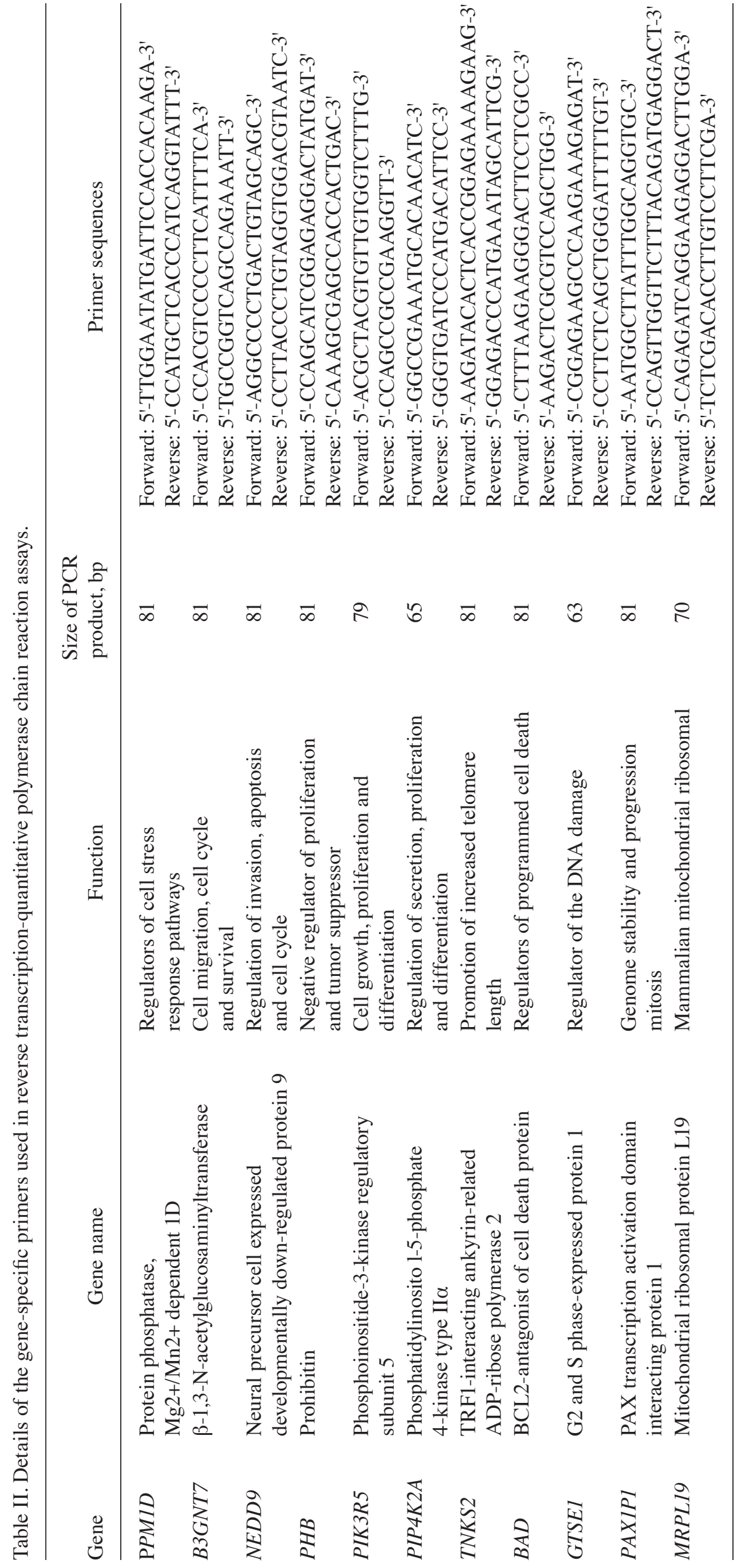



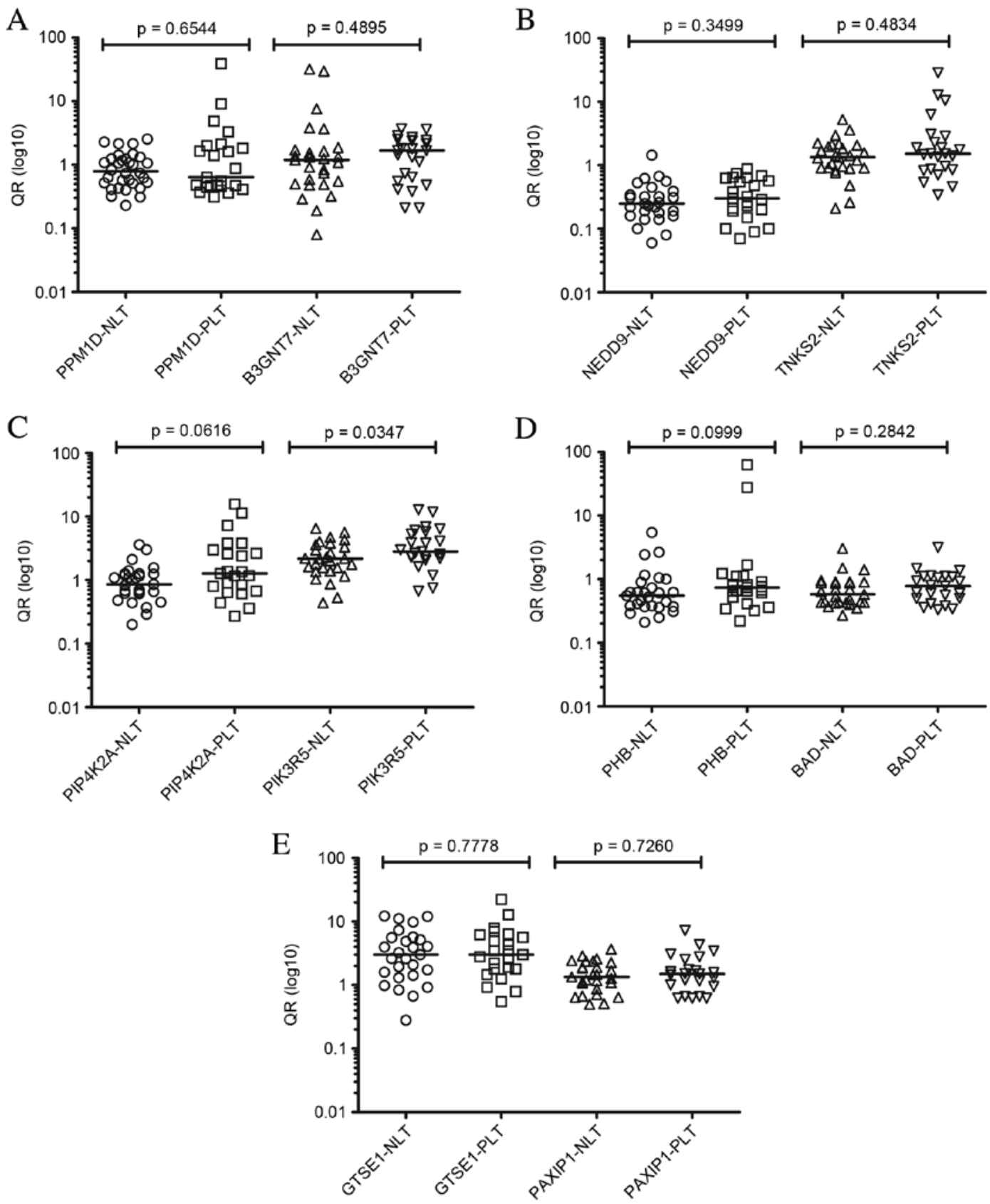

Figure. 1 Comparison between levels of expression by reverse transcription-quantitative polymerase chain reaction of the transcripts (A) PPM1D and B3GNT7, (B) NEDD9 and TNKS2, (C) PIP4K2A and PIK3R5, (D) PHB and BAD and (E) GTSE and PAXIP1 of primary tumors with and without lymph node involvement (analysis 1) with respective P-values. QR, relative quantification; NLT, negative lymph node tumor; PLT, positive lymph node tumor; PPM1D, protein phosphatase $\mathrm{Mg} 2+/ \mathrm{Mn} 2+$ dependent 1D; B3GNT7, $\beta-1,3-\mathrm{N}$-acetylglucosaminyltransferase; NEDD9, neural precursor cell expressed developmentally down-regulated 9; TNKS2, TRF1-interacting ankyrin-related ADP-ribose polymerase 2; PIP4K2A, phosphatidylinositol-5-phosphate 4-kinase type II ; PIK3R5, phosphoinositide-3-kinase regulatory subunit 5; PHB, prohibitin; BAD, BCL2 associated agonist of cell death; GTSE, G2 and S-phase expressed 1; PAXIP1, PAX interacting protein 1.

with breast cancer with lymph node metastasis in two comparisons: i) Primary tumors without lymph node involvement $(\mathrm{n}=27)$ compared with primary tumors with lymph node involvement $(\mathrm{n}=23)$ according to the clinicopathological data (analysis 1); ii) and primary tumor $(\mathrm{n}=11)$ samples compared with corresponding lymph node metastases $(n=11)$ (analysis 2).

When comparing patients with primary tumors without lymph node involvement ( $\mathrm{n}=27$ samples) with patients with lymph node involvement ( $\mathrm{n}=23$ samples) (analysis 1 ), no statistically significant difference was detected for the majority of the genes evaluated. Only the PIK3R5 gene exhibited increased expression in primary tumor samples with lymph node involvement compared with primary tumors without involvement $(\mathrm{P}=0.0347)$. The PIP4K2A gene demonstrated a tendency of increased expression in primary tumors with lymph node involvement compared with those without impairment. For all assessed genes, expression in primary tumors ( $\mathrm{n}=11$ samples) compared with paired lymph node metastases ( $\mathrm{n}=11$ samples) (analysis 2) did not demonstrate any significant differences $(\mathrm{P} \leq 0.05)$. Data from analyses 1 and 2 are presented in Figs. 1 and 2, respectively. 

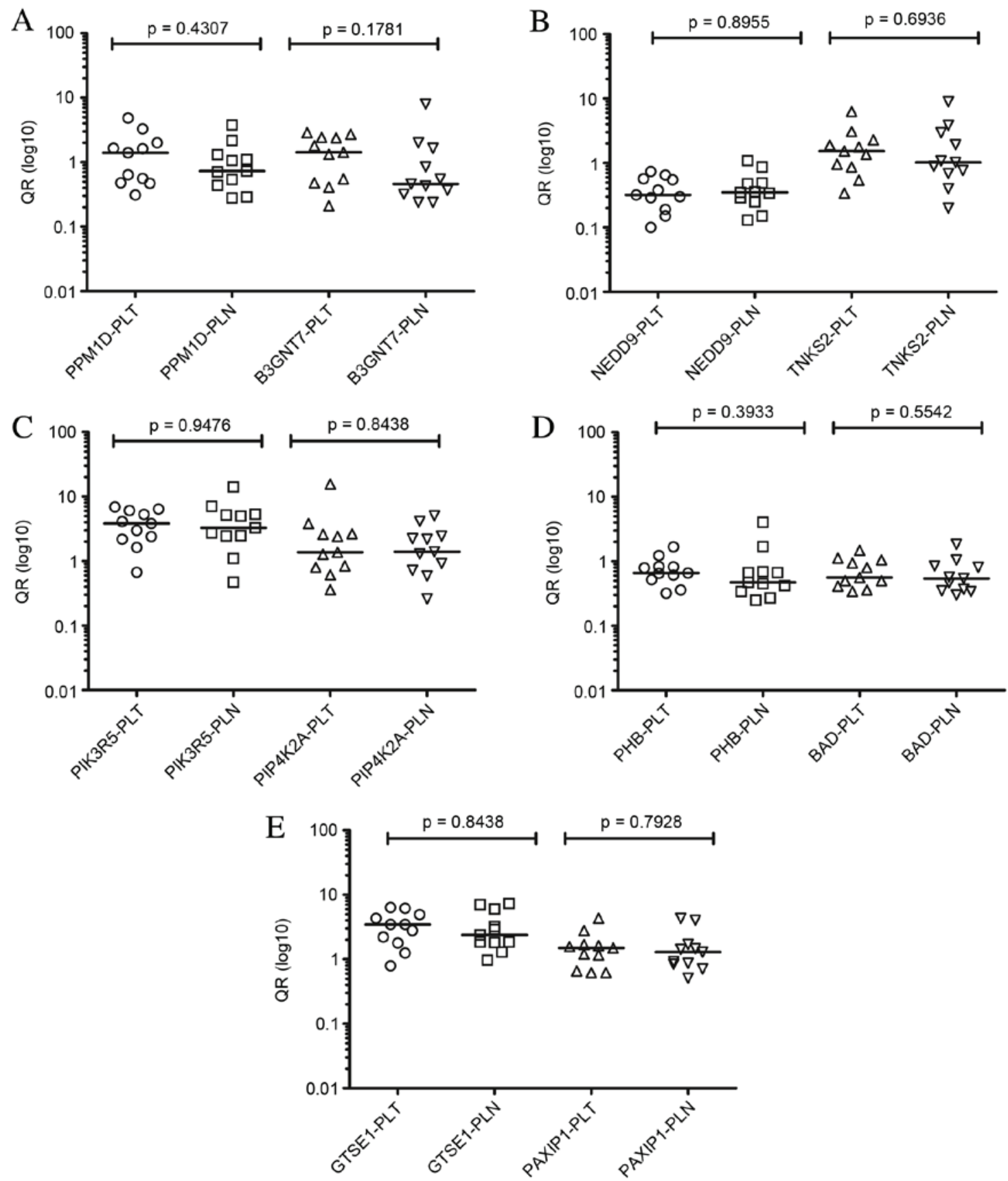

Figure. 2 Comparison between levels of expression by reverse transcription-quantitative polymerase chain reaction of the transcripts (A) PPM1D and B3GNT7, (B) NEDD9 and TNKS2, (C) PIP4K2A and PIK3R5, (D) PHB and BAD and (E) GTSE and PAXIP1 of primary tumors and paired lymph node metastases (analysis 2) with respective P-values. QR, relative quantification; PLT, positive lymph node tumor; PLN, positive lymph node; PPM1D, protein phosphatase $\mathrm{Mg} 2+/ \mathrm{Mn} 2+$ dependent 1D; B3GNT7, $\beta-1,3-\mathrm{N}$-acetylglucosaminyltransferase; NEDD9, neural precursor cell expressed developmentally down-regulated 9; TNKS2, TRF1-interacting ankyrin-related ADP-ribose polymerase 2; PIP4K2A, phosphatidylinositol-5-phosphate 4-kinase type IIa; PIK3R5, phosphoinositide-3-kinase regulatory subunit 5; PHB, prohibitin; BAD, BCL2 associated agonist of cell death; GTSE, G2 and S-phase expressed 1; PAXIP1, PAX interacting protein 1.

\section{Discussion}

Attempts have been made to characterize factors that may predict an increasing risk of nodal involvement, which is the most significant independent prognostic factor in breast cancer and remains the most important feature for defining risk category. Identification of genes involved in the stabilization of metastasis in the lymph nodes may increase the understanding of the metastatic process (27). Differentially-expressed genes may represent those involved in the initiation of metastasis, which alter angiogenesis, cell motility and invasion, therefore allowing primary tumor cells with metastatic potential to disseminate (28). Furthermore, determining the status of these genes may provide key information to establish the potential of these markers as predictors of lymph node involvement. Hence, these markers would serve as molecular targets against which novel therapeutics could be developed to prevent the early stages of metastasis. The identification of molecular markers may spare women at low risk of lymph node metastasis from unnecessary surgical procedures, including ALND, and the 
ensuing complications of lymph node disruption. In addition, this may allow identification of the $8-10 \%$ of node-positive women diagnosed by SLNB as node-negative (29), thus leading to a more accurate prognosis and delineation of a specific treatment for each patient (30). However, based on literature, the data are preliminary and controversial. To date, in spite of assessment of hundreds of markers, few have been used in clinical practice for treatment or prognosis in breast cancer.

To this end, efforts have been made to develop a molecular signature of breast tumors that differs between patients with and without lymph node metastasis. Certain studies have detected a considerable number of genes differentially-expressed in the two groups (31-33). By contrast, a number of research groups have been unable to develop molecular signatures predictive of lymph node metastasis (33-36). Similarly, a previous study failed to detect an effective power in the molecular signature of primary breast tumors associated with lymph node metastasis (27). This study, through evaluation of 41 samples of primary tumors without lymph node involvement and 35 samples with lymph node involvement by microarray analysis, identified only 13 differentially-expressed genes that correctly classified $90 \%$ of negative lymph nodes and only $66 \%$ of lymph node positive tumors (27). The authors suggested that a single molecular classifier for lymph node metastasis may not exist for several factors, including the paucity of cells within the primary tumor with metastatic potential, tumor heterogeneity, effect of the microenvironment or inherited host susceptibility to metastasis (27).

In the present study, the expression of only 1 gene (PIK3R5) of 10 analyzed was significantly different in analysis 1 , with increased expression in samples of primary tumors with lymph node involvement compared with primary tumors without lymph node involvement. This gene serves a role in cell growth, differentiation, proliferation, motility, survival and intracellular transport, and its route is associated with the progression of melanoma $(37,38)$. The PIK3R5 gene is associated with inhibition of autophagy (promoting tumor growth) (39) and certain authors have suggested that autophagy also works as a cytoprotective mechanism (40). In the current study, the PIP4K2A gene exhibited a tendency for increased expression in primary tumors with lymph node involvement compared with those without impairment. This gene is involved in various processes, including cell proliferation, differentiation and motility (41). Myhre et al (41) suggested that $P I P 4 K 2 A$ affects the metastatic process in breast cancer after observing that it was highly expressed in tumors in patients who developed distant metastases compared with patients without metastasis. Increasing the number of samples within a similar study may potentially confirm the predictive value of this gene. Based on these results, the present study observed that of the 10 genes analyzed, only PIK $3 R 5$ may be considered a predictor of lymph node involvement in breast carcinoma, and that although other genes have been characterized to be involved with the development of distant metastasis (21), they did not have predictive potential. The results obtained in the current study are consistent with several studies in the literature that failed to obtain a molecular signature with predictive power $(27,35,36,42)$. Based on these results, it may be concluded that tumor prognosis is independent of the presence or absence of lymph node involvement.
The absence of a signature for lymph node metastasis may be assigned to biological properties of primary tumors, including the nature and number of cells within the primary tumor with metastatic potential. Several studies have reported the presence of small subpopulations of cells with full metastatic potential in localized regions of the primary tumor and that the genetic signatures from these rare cells could be masked by the majority of tumor cells that do not have full metastatic capacity $(43,44)$. These studies do not exclude the ability of the gene expression signatures derived from primary tumors to predict which tumors may metastasize $(27,45,46)$.

In addition, evaluation of gene expression differences between primary breast tumors and matched metastatic lymph nodes should allow genes involved in the metastatic process to be identified. However, in the majority of studies, the status of assessed genes is determined only at the primary tumor, and to the best of our acknowledge, few studies have been published in the literature regarding the evaluation of gene expression, both by microarray and RT-qPCR, which compare primary breast tumors and paired lymph node metastases in breast cancer (47-50).

Contrary to those results (27,43-46), Feng et al (47) hypothesized that metastases in the lymph nodes must originate from a fraction of metastatic cells from primary tumors, and genes differentially-expressed between the primary tumor and corresponding axillary metastasis must serve a key role in metastasis in breast cancer. This study performed a microarray analysis of 21,000 well-characterized genes, and 79 genes with differential expression in 14/26 cases analyzed distinguished primary tumors and corresponding lymph node metastasis samples, establishing a pattern of changes in gene expression associated with the metastatic process (47). Despite identifying similarities between primary breast and paired lymph node metastases, Ellsworth et al (50) detected 51 genes that were differentially-expressed between these two groups; 13 of these genes with higher expression in lymph node metastasis are largely involved in signal transduction, transcription and immune response. This study detected similar classes of genes involved in the comparison of primary tumor with matched lymph node metastases to those obtained by Feng et al (47). However, additional studies observed contradictory results that support a model in which genes involved in changes in extracellular matrix stability are critical to the early metastatic process, while those involved in immune response, signal transduction and proliferation are important for colonization at the secondary site $(48,49)$.

In the present study, the expression analysis of 10 genes from primary tumors and corresponding lymph node metastases (analysis 2) was conducted. The results did not detect significant differences in the expression of any of the evaluated genes in each group. These results are consistent with the hypothesis that only a fraction of cells, which are phenotypically and biologically heterogeneously localized in certain regions of the primary tumor, have higher metastatic potential $(27,51)$. This may explain why changes in expression of specific genes with predictive potential, including PIK3R5, cannot be detected in the primary tumor; molecular alterations of these rare cells are able to be masked by cells of the primary tumor that lack a high metastatic capacity. An additional factor 
that may explain the inability to detect the differential expression of this gene between primary tumors and corresponding lymph nodes is that it could only be detected if the tumors of the majority of these patients were already involved in the metastatic process. In the current study, only $2 / 11$ patients with positive lymph nodes presented with distant metastases. Presently, for therapeutic purposes, it is assumed that the molecular phenotype of the primary tumor is the same as that for lymph node involvement; however, it should be noted that there is great heterogeneity in tumors, and that, over time, affected lymph nodes may acquire novel biological characteristics and different forms of invasion, blood or lymph, thus leading to failures in treatment (52).

In conclusion, the present study identified that PIK3R5 exhibited differential expression between node-positive and node-negative primary tumors. This gene serves a role in cell growth, differentiation, proliferation, motility, survival and intracellular transport, and the results of the current study demonstrate that it should be considered as a predictor of lymph node involvement in breast carcinoma. Although the majority of the evaluated genes have been characterized in previous studies as prognostic markers involved in the development of distant metastases, they did not have predictive potential in the present study. Further studies with a larger number of samples are required to confirm these results, and novel molecular markers are necessary to effectively discriminate patients with and without the propensity to develop lymph node metastasis, therefore sparing low-risk women from the morbidities associated with surgical evaluation and reducing the false-negative rate associated with SLNB.

\section{Acknowledgements}

The authors would like to thank Miss Jéssica Camila da Silva for her technical assistance regarding RNA extraction, Dr Edgard Franco de Moraes Coutinho (Esteticlin Clinic, São José dos Campos, Brazil) for providing healthy control tissues, Dr Jose Spartaco Vial (Clinica Pro Onco, São José dos Campos, Brazil) for providing tumor tissues and Miss Alene Alder-Rangel (Alder's English Services, University of Paraíba Valley, São José dos Campos, Brazil) for reviewing the English in the original manuscript. The present study was partially supported by a research grant from the Foundation for Research Support of the State of São Paulo (FAPESP), Brazil.

\section{References}

1. Tang Y, Xu F, Tao K, Qian N and Toi M: Clinical applications of sentinel lymph node biopsy in ductal carcinoma in situ of the breast: A dilemma. Tohoku J Exp Med 224: 1-5, 2011.

2. Calhoun BC and Collins LC: Predictive markers in breast cancer: An update on ER and HER2 testing and reporting. Semin Diagn Pathol 32: 362-369, 2015.

3. Howat JM, Barnes DM, Harris M and Swindell R: The association of cytosol oestrogen and progesterone receptors with histological features of breast cancer and early recurrence of disease. Br J Cancer 47: 629-640, 1983.

4. Fisher ER, Costantino J, Fisher B and Redmond C: Pathologic findings from the National Surgical Adjuvant Breast Project (Protocol 4). Discriminants for 15-year survival. National Surgical Adjuvant Breast and Bowel Project Investigators. Cancer 71 (Suppl 6): 2141-2150, 1993.

5. Pantel K and Brakenhoff RH: Dissecting the metastatic cascade. Nat Rev Cancer 4: 448-456, 2004.
6. Ponzone R, Maggiorotto F, Mariani L, Jacomuzzi ME, Magistris A, Mininanni P, Biglia N and Sismondi P: Comparison of two models for the prediction of nonsentinel node metastases in breast cancer. Am J Surg 193: 686-692, 2007.

7. Gurleyik G, Aker F, Aktekin A and Saglam A: Tumor characteristics influencing non-sentinel lymph node involvement in clinically node negative patients with breast cancer. J Breast Cancer 14: 124-128, 2011.

8. Wallwiener CW, Wallwiener M, Kurth RR, Röhm C, Neubauer H, Banys MJ, Staebler A, Schönfisch B, Meuer SC, Giese T and Fehm TN: Molecular detection of breast cancer metastasis in sentinel lymph nodes by reverse transcriptase polymerase chain reaction (RT-PCR): Identifying, evaluating and establishing multi-marker panels. Breast Cancer Res Treat 130: 833-844, 2011.

9. Cavalli LR: Molecular markers of breast axillary lymph node metastasis. Expert Rev Mol Diagn 9: 441-454, 2009.

10. Yenidunya S, Bayrak R and Haltas H: Predictive value of pathological and immunohistochemical parameters for axillary lymph node metastasis in breast carcinoma. Diagn Pathol 6: 18, 2011.

11. Cserni G, Burzykowski T, Vinh-Hung V, Kocsis L, Boross G, Sinkó M, Tarján M, Bori R, Rajtár M, Tekle E, et al: Axillary sentinel node and tumour-related factors associated with non-sentinel node involvement in breast cancer. Jpn J Clin Oncol 34: 519-524, 2004.

12. Hung WK, Chan MC, Mak KL, Chong SF, Lau Y, Ho CM and Yip AW: Non-sentinel lymph node metastases in breast cancer patients with metastatic sentinel nodes. ANZ J Surg 75: 27-31, 2005.

13. Marrazzo A, Boscaino G, Marrazzo E, Taormina P and Toesca A: Breast cancer subtypes can be determinant in the decision making process to avoid surgical axillary staging: A retrospective cohort study. Int J Surg 21: 156-161, 2015.

14. Veronesi U, Galimberti V, Zurrida S, Pigatto F, Veronesi P, Robertson C, Paganelli G, Sciascia V and Viale G: Sentinel lymph node biopsy as an indicator for axillary dissection in early breast cancer. Eur J Cancer 37: 454-458, 2001.

15. Newman EA and Newman LA: Lymphatic mapping techniques and sentinel lymph node biopsy in breast cancer. Surg Clin North Am 87: 353-364, viii, 2007.

16. Blumencranz PW, Pieretti M, Allen KG and Blumencranz LE: Molecular analysis of breast sentinel lymph nodes. Surg Oncol Clin N Am 20: 467-485, viii, 2011.

17. Backus J, Laughlin T, Wang Y, Belly R, White R, Baden J, Justus Min C, Mannie A, Tafra L, Atkins D and Verbanac KM: Identification and characterization of optimal gene expression markers for detection of breast cancer metastasis. J Mol Diagn 7: 327-336, 2005.

18. Abdul-Rasool S, Kidson SH, Panieri E, Dent D, Pillay K and Hanekom GS: An evaluation of molecular markers for improved detection of breast cancer metastases in sentinel nodes. J Clin Pathol 59: 289-297, 2006.

19. Patani NR, Dwek MV and Douek M: Predictors of axillary lymph node metastasis in breast cancer: A systematic review. Eur J Surg Oncol 33: 409-419, 2007.

20. Kurosumi M and Takei H: Significance and problems of histopathological examination and utility of real-time reverse transcriptase-polymerase chain reaction method for the detection of sentinel lymph node metastasis in breast cancer. Breast Cancer 14: 342-349, 2007.

21. Canevari RA, Marchi FA, Domingues MA, de Andrade VP, Caldeira JR, Verjovski-Almeida S, Rogatto SR and Reis EM: Identification of novel biomarkers associated with poor patient outcomes in invasive breast carcinoma. Tumor Biol: Aug 2, 2016. (Epub ahead of print)

22. World Health Organization: International Classification of Diseases for Oncology, Third Edition. World Health Organization, Geneva, 2000.

23. UICCTMN: Classificação dos Tumores Malignos. In: Ministério da Saúde. 7th edition. Rio de, Janeiro, 2007.

24. Bloom HJ and Richardson WW: Histological grading and prognosis in breast cancer; a study of 1409 cases of which 359 have been followed for 15 years. Br J Cancer 11: 359-377, 1957.

25. Pfaffl MW: A new mathematical model for relative quantification in real-time RT-PCR. Nucleic Acids Res 29: e45, 2001.

26. McNeill RE, Miller N and Kerin MJ: Evaluation and validation of candidate endogenous control genes for real-time quantitative PCR studies of breast cancer. BMC Mol Biol 8: 107, 2007.

27. Ellsworth RE, Field LA, Love B, Kane JL, Hooke JA and Shriver CD: Differential gene expression in primary breast tumors associated with lymph node metastasis. Int J Breast Cancer 2011: 142763, 2011. 
28. Nguyen DX and Massagué J: Genetic determinants of cancer metastasis. Nat Rev Genet 8: 341-352, 2007.

29. Michaelson JS, Silverstein M, Sgroi D, Cheongsiatmoy JA, Taghian A, Powell S, Hughes K, Comegno A, Tanabe KK and Smith B: The effect of tumor size and lymph node status on breast carcinoma lethality. Cancer 98: 2133-2143, 2003.

30. Mansel RE, Goyal A and Newcombe RG; ALMANAC Trialists Group: Internal mammary node drainage and its role in sentinel lymph node biopsy: The initial ALMANAC experience. Clin Breast Cancer 5: 279-286, 2004.

31. Bertucci F, Houlgatte R, Benziane A, Granjeaud S, Adélaïde J, Tagett R, Loriod B, Jacquemier J, Viens P, Jordan B, et al: Gene expression profiling of primary breast carcinomas using arrays of candidate genes. Hum Mol Genet 9: 2981-2991, 2000.

32. Huang E, Cheng SH, Dressman H, Pittman J, Tsou MH, Horng CF, Bild A, Iversen ES, Liao M, Chen CM, et al: Gene expression predictors of breast cancer outcomes. Lancet 361: 1590-1596, 2003.

33. Abba MC, Sun H, Hawkins KA, Drake JA, Hu Y, Nunez MI, Gaddis S, Shi T, Horvath S, Sahin A, et al: Breast cancer molecular signatures as determined by SAGE: Correlation with lymph node status. Mol Cancer Res 5: 881-890, 2007.

34. van't Veer LJ, Dai H, van de Vijver MJ, He YD, Hart AA, Mao M, Peterse HL, van der Kooy K, Marton MJ, Witteveen AT, et al: Gene expression profiling predicts clinical outcome of breast cancer. Nature 415: 530-536, 2002

35. Weigelt B, Hu Z, He X, Livasy C, Carey LA, Ewend MG Glas AM, Perou CM and Van't Veer LJ: Molecular portraits and 70-gene prognosis signature are preserved throughout the metastatic process of breast cancer. Cancer Res 65: 9155-9158, 2005.

36. Lu X, Lu X, Wang ZC, Iglehart JD, Zhang X and Richardson AL: Predicting features of breast cancer with gene expression patterns. Breast Cancer Res Treat 108: 191-201, 2008.

37. Gray-Schopfer V, Wellbrock C and Marais R: Melanoma biology and new targeted therapy. Nature 445: 851-857, 2007.

38. Shull AY, Latham-Schwark A, Ramasamy P, Leskoske K, Oroian D, Birtwistle MR and Buckhaults PJ: Novel somatic mutations to PI3K pathway genes in metastatic melanoma. PLoS One 7: e43369, 2012.

39. Ávalos Y, Canales J, Bravo-Sagua R, Criollo A, Lavandero S and Quest AF: Tumor suppression and promotion by autophagy. BioMed Res Int 2014: 603980, 2014.

40. Orzechowski A, Bettuzzi S, Pawlikowska P and Pajak B: Control of autophagy in cancer. Biomed Res Int 2015: 698740, 2015.
41. Myhre S, Mohammed H, Tramm T, Alsner J, Finak G, Park M, Overgaard J, Børresen-Dale AL, Frigessi A and Sørlie T: In silico ascription of gene expression differences to tumor and stromal cells in a model to study impact on breast cancer outcome. PLoS One 5: e14002, 2010.

42. van de Vijver MJ, He YD, van't Veer LJ, Dai H, Hart AA, Voskuil DW, Schreiber GJ, Peterse JL, Roberts C, Marton MJ, et al: A gene-expression signature as a predictor of survival in breast cancer. N Engl J Med 347: 1999-2009, 2002.

43. Kang Y, Siegel PM, Shu W, Drobnjak M, Kakonen SM, Cordón-Cardo C, Guise TA and Massagué J: A multigenic program mediating breast cancer metastasis to bone. Cancer Cell 3: 537-549, 2003

44. Ding L, Ellis MJ, Li S, Larson DE, Chen K, Wallis JW, Harris CC, McLellan MD, Fulton RS, Fulton LL, et al: Genome remodelling in a basal-like breast cancer metastasis and xenograft. Nature 464: 999-1005, 2010.

45. Fidler IJ and Kripke ML: Genomic analysis of primary tumors does not address the prevalence of metastatic cells in the population. Nat Genet 34: 23, 2003.

46. Welch DR: Microarrays bring new insights into understanding of breast cancer metastasis to bone. Breast Cancer Res 6: 61-64, 2004.

47. Feng Y, Sun B, Li X, Zhang L, Niu Y, Xiao C, Ning L, Fang Z, Wang Y, Zhang L, et al: Differentially expressed genes between primary cancer and paired lymph node metastases predict clinical outcome of node-positive breast cancer patients. Breast Cancer Res Treat 103: 319-329, 2007.

48. Suzuki M and Tarin D: Gene expression profiling of human lymph node metastases and matched primary breast carcinomas: Clinical implications. Mol Oncol 1: 172-180, 2007.

49. Vecchi M, Confalonieri S, Nuciforo P, Viganò MA , Capra M, Bianchi M, Nicosia D, Bianchi F, Galimberti V, Viale G, et al: Breast cancer metastases are molecularly distinct from their primary tumors. Oncogene 27: 2148-2158, 2008

50. Ellsworth RE, Seebach J, Field LA, Heckman C, Kane J, Hooke JA, Love B and Shriver CD: A gene expression signature that defines breast cancer metastases. Clin Exp Metastasis 26: 205-213, 2009

51. Yokota J: Tumor progression and metastasis. Carcinogenesis 21: 497-503, 2000

52. Chambers AF, Naumov GN, Vantyghem SA and Tuck AB: Molecular biology of breast cancer metastasis. Clinical implications of experimental studies on metastatic inefficiency. Breast Cancer Res 2: 400-407, 2000. 